\title{
ANALISIS TERHADAP FATWA DEWAN SYARI'AH NASIONAL MAJELIS ULAMA INDONESIA (DSN- MUI) TENTANG UANG ELEKTRONIK SYARIAH (Studi Kartu Flazz BCA, Go-Pay, dan Grab-Pay)
}

\author{
Novia Nengsih \\ Institut Agama Islam Negeri (IAIN) Batusangkar \\ Email: novianengsih24@gmail.com
}

\section{Abstract}

Technological developments have transformed the cash-money payment model into e-money, but the law on the use of e-money is still a debate in Indonesian Moslim society. Thispaper aims to analyze the legal use of e-money based on DSN-MUI fatwa No: 116/DSN-MUI/IX/2017 concerning Sharia Electronic Money. This research is a library research with descriptive analysis approach. E-money that was studied in this study was the BCA Flazz cards, Go-Pay, and Grab-Pay. Based on the Fatwa of MUI DSN on Shariah electronic money, the e-money system used in Indonesia today is not permitted because the issuer places the nominal amount of electronic money in conventional banks, if the card is lost the nominal amount of money in the issuer is also lost, and electronic money holders cannot be taken or cashed back.

Perkembangan teknologi telah mentransformasi modelpembayaran dari cash-money menjadi e-money, tetapi hukum penggunaan e-money masib menjadi perdebatan di kalangan masyarakat Muslim Indonesia. Tulisan ini bertujuan untuk menganalisis bukum penggunaan e-money berdasarkan fatwa DSN-MUI No: 116/DSN-MUI/ IX/2017 tentang Uang Elektronik Syariah. Penelitian ini merupakan penelitian kepustakaan (library research) dengan menggunakan pendekatan deskriptif analisis. E-money yang menjadi kajian dalam penelitian ini adalah kartu Flazz BCA, GoPay, dan Grab-Pay. Berdasarkan fatwa DSN MUI tentang Uang elektronik Syariah, maka sistem e-money yang dipakai di Indonesia hari ini tidak diperbolehkan karena 
penerbit menempatkan jumlah nominal uang elektronik di bank konvensional, apabila kartu hilang maka jumlah nominal uang yang ada dipenerbit juga bilang, dan uang elektronik pemegang tidak bisa diambil atau diuangkan kembali.

Keywords: sharia electronic money, shariah, muslim

\section{Pendahuluan}

Perkembangan teknologi dan informasi telah mentransformasi kehidupan manusia, salah satunya dalam financial technology (fintech) yang memunculkan inovasi baru dalam penyelenggaraan transaksi pembayaran secara elektronik guna memaksimalkan penggunaan alat pembayaran non tunai. ${ }^{1}$ Perkembangan teknologi telah membawa suatu perubahan kebutuhan masyarakat atas suatu alat pembayaran yang dapat memenuhi kecepatan, ketepatan, dan keamanan dalam setiap transaksi elektronik. Sejarah membuktikan perkembangan alat pembayaran terus berubah-ubah bentuknya, mulai dari bentuk logam, uang kertas konvensional, hingga kini alat pembayaran telah mengalami evolusi berupa data yang dapat ditempatkan pada suatu wadah atau disebut dengan alat pembayaran elektronik. ${ }^{2}$

Saat ini, situasi yang dihadapi justru terjadinya pergeseran dari uang kertas ke uang elektronik. ${ }^{3}$ Perkembangan alat pembayaran berupa uang elektronik yang sebelumnya diatur sebagai kartu prabayar tidak hanya diterbitkan dalam bentuk kartu namun juga telah berkembang dalam bentuk lainnya. Seiring dengan perkembangan teknologi informasi dan komunikasi, alat pembayaran berupa uang elektronik yang diterbitkan oleh bank maupun lembaga selain bank saat ini semakin berkembang.

Dalam perkembangannya, sistem pembayaran secara elektronik atau bisa disebut non-tunai sangat dipengaruhi oleh kemajuan perkembangan teknologi dan perubahan pola hidup masyarakat. Saat ini perkembangan instrumen pembayaran non tunai berjalan sangat pesat seiring dengan perkembangan teknologi sistem pembayaran yang pada akhir-akhir ini telah membawa dampak yang besar terhadap pihak-pihak yang terlibat dalam sistem pembayaran tersebut. Dengan dukungan teknologi yang semakin maju, masyarakat pengguna maupun penyedia jasa sistem pembayaran non tunai secara terus menerus mencari alternatif instrumen

1 Rachmadi Usman, "Karakteristik Uang Elektronik dalam Sistem Pembayaran” Yuridika: Vol. 32 No. 1, (Januari, 2017): 134-166.

2 Muhammad Sofyan Abidin, "Dampak Kebijakan E-Money di Indonesia Sebagai Alat Sistem Pembayaran Baru” Jurnal Akuntansi UNESA, Vol 3, No 2, (2015): 1-21.

3 Victoria Insley and Daniel Nunan, "Gamification and the online retail experience", International Journal of Retail \& amp; Distribution Management, Vol. 42, Issue 5, (2014): 340-351. 
pembayaran non tunai yanglebih efisien dan aman. Selain itu, perubahan pola hidup masyarakat yang disertai peningkatan efisiensi pola hidup menuntut tersedianya sarana telekomunikasi dan trasportasi yang demikian cepat sehingga hambatan jarak dan waktu dapat dikurangi. Perkembangan telekomunikasi dan transportasi ini juga memberikan pengaruh yang besar terhadap transaksi keuangan terutama terkait dengan cara antar pihak melakukan pembayaran.

Alat pembayaran elektronik (e-money) terus berkembang sampai hari ini. Perkembangan e-money mampu menciptakan suatu trendless cash society, yaitu suatu perilaku masyarakat yang menggunakan transaksi non tunai, dengan memanfaatkan kemudahan-kemudahan yang ditawarkan oleh alat-alat transaksi elektronik tersebut. ${ }^{4}$ Eny Sri Hartati, Direktur Eksekutif Institute for Development of Economics and Finance (INDEF), mengatakan penggunaan uang elektronik mempercepat transaksi dan proses perdagangan.

Data dari Bank Indonesia menyebut, hingga September 2016 volume transaksi sebesar 476, 56 juta dengan nilai transaksi 4, 89 triliun Rupiah dan jumlah e-money beredar sebanyak 352, 07 juta. Di 2014, volume transaksi mencapai 203, 38 juta atau naik $47,48 \%$ secara year-on-year (yoy) dibanding tahun sebelumnya. Kemudian, 535,57 juta transaksi di 2015 atau setara dengan kenaikan 163, 35\%. Dari segi nominal transaksi, di 2014 sebanyak 3, 31 triliun Rupiah, naik 14, 17\%. Di tahun berikutnya menjadi 5, 28 triliun Rupiah, naik 59, 17\%. ${ }^{5}$

E-money merupakan sistem pembayaran yang efisien dan ramah pengguna, baik digunakan sebagai alat pembayaran umum di dunia nyata ataupun virtual. ${ }^{6}$ Tingginya angka perkembangan e-money di Indonesia ini membuktikan bahwa transformasi cash-money menuju e-money benar-benar terjadi dengan sangat cepat. Tetapi, sebagai negara dengan mayoritas penduduk Muslim, tidak bisa dipungkiri bahwa wacana tentang kebolehan menggunakan e-money belakangan ini semakin merebak. Menyikapi hal ini, maka penulis tertarik melakukan analisis tentang hukum menggunakan e-money di Indonesia berdasarkan fatwa DSN-MUI No: 116/DSN-MUI/IX/2017 tentang Uang Elektronik Syariah. Analisis ini dilakukan pada kartu Flazz BCA, Go-Pay, dan Grab-Pay. Ketiga hal ini merupakan e-money yang paling banyak digunakan oleh masyarakat Indonesia terutama dalam bidang transportasi.

4 Ikaputera Waspada, "Percepatan Adopsi Sistem Transaksi Teknologi Informasi Untuk Meningkatkan Aksesibilitas Layanan Jasa Perbankan” Jurnal Keuangan dan Perbankan, Vol.16, No.1 (Januari, 2012): 122-131.

5 www.bi.go.id

6 Victoria Insley and Daniel Nunan,"Gamification and the online retail experience", International Journal of Retail \&amp; Distribution Management, Vol. 42, Issue 5, (2014): 340-351. 


\section{Metode Penelitian}

Penelitian ini merupakan penelitian kepustakaan (library research). Data-data yang digunakan dalam penelitian ini adalah data sekunder berupa fatwa DSNMUI No: 116/DSN-MUI/IX/2017 tentang Uang Elektronik Syariah, data-data terkait e-money khususnya Flazz BCA, Go-Pay, dan Grab-Pay, serta sumber lainnya berupa buku, jurnal, dan sumber-sumber lain yang relevan dengan penelitian ini. Data-data yang ada tersebut dianalisis menggunakan teknik deskriptif analisis.

\section{Pembahasan}

\section{Konsep Uang Dalam Islam}

Sebelum bicara lebih jauh tentang uang elektronik, maka penting untuk didudukkan terlebih dahulu tentang konsep uang dalam Islam. Hal ini dimaksudkan untuk menyamakan persepsi tentang pemaknaan uang itu sendiri, karena uang dalam konsep ekonomi konvensional memiliki perbedaan dengan uang dalam konsep ekonomi Islam.

Dalam ekonomi Islam, uang adalah uang, uang bukan capital. Sebaliknya konsep uang dalam ekonomi konvensional tidak jelas. Sering kali istilah uang dalam perspektif ekonomi konvensional diartikan secara bolak-balik (interchangeability), yaitu uang sebagai uang dan uang sebagai capital. ${ }^{7}$ Uang memiliki fungsi sebagai penyimpan nilai yang kemudian berkembang menjadi motif money of demand for speculation, yang merubah fungsi uang sebagai salah satu komoditi perdagangan. Sebagai komoditi, maka uang bisa menghasilkan uang.

Uang dalam literatur fiqh disebut dengan tsaman atau nuqud. Uang (naqd) adalah segala sesuatu yang menjadi media pertukaran dan diterima secara umum, apapun bentuk dan dalam kondisi seperti apapun media tersebut. ${ }^{8}$ Dalam ekonomi Islam, uang merupakan sesuatu yang bersifat flow concept dan capital adalah sesuatu yang bersifat stock concept, sedangkan dalam ekonomi konvensional terdapat beberapa pengertian. Irving Fisher sebagaimana dikutip oleh Frederic S. Miskin mengemukakan konsep uang sebagai berikut:"

$\mathrm{MV}=\mathrm{PT}$

\section{Keterangan:}

$$
\mathrm{M}=\text { Jumlah Uang }
$$

7 Colin Rogers, Money, Interest and Capital: A Study in the Foundation of Monetery Theory, (Cambridge: Cambridge University Press, 1989), 76.

8 Abdullah bin Sulaiman al-Mani', Buhuts fi al-iqtishad al-Islami (Mekah: al-Maktab al-Islami, 1996), 178.

9 Frederic S. Miskin, The Economic of Money, Banking, and Financial Market, (New York: Addison Wesley Longman, 2001), $538-539$. 


$$
\begin{aligned}
& \mathrm{V}=\text { Tingkat Peputaran Uang } \\
& \mathrm{P}=\text { Tingkat Harga Barang } \\
& \mathrm{T}=\text { Jumalah Barang yang diperdagangkan }
\end{aligned}
$$

Dari persamaan di atas terlihat bahwa semakin cepat perputaran uang, maka semakin besar income yang diperoleh. Persamaan tersebut juga menjelaskan bahwa uang adalah flow concept. Konsep Irfing Fisher ini hampir sama dengan konsep ekonomi Islam bahwa uang adalah flow concept.

Berbeda dengan Fisher, Marshall Pigou sebagaimana dikutip oleh Frederic S. Miskin menjelaskan konsep uang sebagai berikut: ${ }^{10}$

$$
\mathrm{M}=\mathrm{kPT}
$$

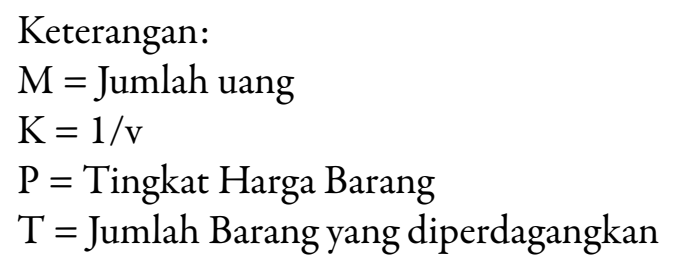

Dari persamaan Pigou ini terlihat bahwa uang adalah stock concept. Oleh karena itu, Pigou mengatakan bahwa uang merupakan salah satu cara untuk

\begin{tabular}{|c|c|}
\hline Konsep Islam & Konsep Konvensional \\
\hline - Uang tidak identik dengan modal & $\begin{array}{l}\text { Uang seringkali diidentikkan dengan } \\
\text { modal }\end{array}$ \\
\hline - Uang adalah public goods & Uang (modal) adalah private goods \\
\hline - Modal adalah private goods & $\begin{array}{l}\text { Uang (modal) adalah flow concept } \\
\text { bagi Fisher }\end{array}$ \\
\hline - Uang adalah flow concept & $\begin{array}{l}\text { Uang (Modal) adalah stock concept } \\
\text { bagi Pigou }\end{array}$ \\
\hline - Modal adalah stock concept & \\
\hline
\end{tabular}
menyimpan kekayaan (store of wealth). Adiwarman A. Karim menjelaskan konsep uang menurut Islam dan konvensioanl sebagai berikut: ${ }^{11}$

Tabel 1. Konsep menurut Islam dan konvensional

Pemikiran Al-Ghazali yang juga cukup menakjubkan tentang fungsi uang adalah teorinya yang menyatakan bahwa uang diibaratkan cermin yang tidak

10 Frederic S. Miskin, The Economic of Money, Banking, and Financial Market, (New York: Addison Wesley Longman, 2001), 540 - 541.

11 Adiwarman A. Karim, Ekonomi Makro Islami, (Jakarta: PT. Raja Grafindo Persada, 2008), 79. 
mempunyai warna, tetapi dapat merefleksikan semua warna. Maksudnya, uang tidak memiliki harga (intrinsik) tetapi dapat merefleksikan semua harga. Dalam istilah ekonomi klasik dikatakan, uang tidak memberi kegunaan langsung (direct utility function). Hanya bila uang itu digunakan untuk membeli barang, barulah barang itu memiliki kegunaan. ${ }^{12}$

Dalam ekonomi Islam sebagaimana dijelaskan al-Ghazali, fungsi uang adalah sebagai media pertukaran dan standar harga barang. Siapa yang menggunakan uang tidak sesuai dengan fungsinya, berarti dia telah kufur nikmat dalam penggunaan uang. Menimbun uang merupakan tindakan tercela dalam perspektif ekonomi Islam, karena ia telah memenjarakan uang dan mencegah fungsi sebenarnya. Menurut al-Ghazali, penimbunan uang persis seperti orang yang memenjarakan hakim kaum muslimin, sehingga kelancaran perasidangan hukum terhambat. Kalau uang itu disimpan saja, maka hikmat-hikmatnya pun akan hilang dan tujuan dari adanya uang itu tidak terwujud. ${ }^{13}$

\section{Uang Elektronik dan Uang Elektronik Syariah}

Menurut Bank for International Settlement(BIS) dalam publikasinya pada tahun 1996 mendefinisikan uang elektronik sebagai "stored value or prepaid products in which a record of the funds or value available to a costumer is stored on an elektronic device in the costumer's possession". ${ }^{14}$ E-money merupakan produk stored-value atau prepaid card dimana sejumlah nilai uang (monetary value) disimpan secara elektronik dalam suatu peralatan elektronik. Nilai elektronik dapat diperoleh dengan menyetorkan sejumlah uang tunai atau dengan pendebetan rekeningnya di bank untuk kemudian disimpan dalam peralatan elektronik miliknya. Dengan peralatan tersebut pemilik dapat melakukan pembayaran atau menerima pembayaran, dimana nilainya akan berkurang pada saat digunakan untuk melakukan pembayaran atau bertambah jika menerima pembayaran atau pada saat pengisian kembali.

Di Indonesia, uang elektronik diatur dalam Peraturan Bank Indonesia Nomor: 11/12/PBI/2009 tentang Uang Elektronik (electronic money). Dalam ketentuan pasal 1 ayat 3 PBI ini disebutkan bahwa Uang Elektronik (Electronic Money) adalah alat pembayaran yang memenuhi unsur-unsur sebagai berikut: ${ }^{15}$

a. Diterbitkan atas dasar nilai uang yang disetor terlebih dahulu oleh pemegang kepada penerbit;

12 Adiwarman A. Karim, Ekonomi Makro Islami,80

13 Adiwarman A. Karim, Ekonomi Makro Islami, 81.

14 Bank for Internatinal Settlement, Implications for central bank of the development of electronic money,

(Basel: BIS, 1996), 1.

15 Peraturan Bank Indonesia Nomor: 11/12/PBI/2009 tentang Uang Elektronik (electronic money). 
b. Nilai uang disimpan secara elektronik dalam suatu media seperti server atau chip;

c. Digunakan sebagai alat pembayaran kepada pedagang yang bukan merupakan penerbit uang elektronik tersebut;

d. Nilai uang elektronik yang disetor oleh pemegang dan dikelola oleh penerbit bukan merupakan simpanan sebagaimana dimaksud dalam undang-undang yang mengatur mengenai perbankan.

Batasan e-money seperti tersebut di atas, tidak jauh berbeda dengan yang dikemukakan oleh the Consultative Group to Assist the Poor (CGAP) sebagai lembaga supervisi di bawah Bank Dunia, e-money diartikan sebagai berikut:

"While there are slight variations across countries, e-money is typically defined as a type of "stored value" instrument or product that (i) is issued on receipt of funds, (ii) consists of electronically recorded value stored on a device (i.e., a computer system, mobile phone, prepaid card, or chip), (iii) is accepted as a means of payment by parties other than the issuer, and (iv) is convertible into cash". ${ }^{16}$

Demikian juga dalam report on electronic money oleh the Group of Ten, e-money diartikan sebagai berikut:

"New electronic means of retail payment that are currently being tested or implemented in a number of markets include multi-purpose prepaid cards, sometimes called "electronic purses" or "stored-value cards", and prepaid or stored-value payment mechanisms for executing ayments over open computer networks, such as the Internet. For the purposes of this report, these products are referred to as electronic money. A precise definition of electronic money is difficult to provide; indeed, a number of official bodies have described and categorised these products in different ways." ${ }^{17}$

Uang elektronik pada hakikatnya merupakan uang tunai tanpa ada fisik (casbless money), yang nilai uangnya berasal dari nilai uang yang disetor terlebih dahulu kepada penerbitnya, kemudian disimpan secara elektronik dalam suatu media elektronik berupa server ( hard drive) atau kartu chip, yang berfungsi sebagai alat pembayaran non tunai kepada pedagang yang bukan penerbit uang elektronik yang bersangkutan. Nilai uang (monetary value) pada uang elektronik tersebut berbentuk elektronik (nilai elektronis) yang didapat dengan cara menukarkan sejumlah uang tunai atau pendebitan rekeningnya di bank untuk kemudian disimpan secara elektronik dalam media elektronik berupa kartu penyimpan dana (stored value card).

Adapun perbedaannya dengan kartu ATM, kartu debit atau kartu kredit, nilai uangnya tersimpan pada rekening nasabah yang bersangkutan di bank,

16 Kate Lauer dan Michael Tarazi, 'Supervising Nonbank E-Money Issuers' (CGAP, 2010) <www.cgap. org/.../CGAP-Brief-Supervising-Nonbank-Emoney-> accessed 11 March 2018.

17 Committee on Payment and Settlement Systems, Survey of Developments in Electronic Money and Internet and Mobile Payments (Bank for International Settlements 2004). 
sedangkan pada uang elektronik, nilai uangnya tersimpan pada perangkat sistem komputer, ponsel, kartu prabayar atau kartu chip. Selanjutnya, ketika pemegang uang elektronik melakukan transaksi pembayaran atau transfer dana, maka nilai uang yang terdapat dalam uang elektronik tersebut juga akan berkurang sesuai dengan nilai transaksi pembayaran atau transfer dana yang dilakukan layaknya seperti uang tunai. Sebaliknya nilai uang dalam uang elektronik dapat bertambah bila menerima pembayaran atau pada saat pengisian ulang. ${ }^{18}$

Veithzal Rifai menjelaskan bahwa yang dimaksud dengan uang elektronik adalah alat pembayaran elektronik yang diperoleh dengan menyetorkan terlebih dahulu sejumlah uang kepada penerbit, atau dengan pendebitan rekening di Bank, dan nilai uang tersebut dimasukkan menjadi nilai uang dalam media elektronik yang digunakan dalam satuan rupiah yang digunakan untuk melakukan transaksi pembayaran dengan cara mengurangi nilai uang secara langsung pada media elektronik tersebut. ${ }^{19}$

Menurut Warjiyo sebagaimana dikutip oleh Ikaputera Waspada bahwa alat pembayaran non tunai memberikan manfaat kepada perekonomian, antara lain: tingkat kepuasan konsumen yang semakin bertambah dengan berkurangnya biaya transaksi, adanya sumber pendapatan bagi penyedia jasa pembayaran non tunai, peningkatan kecepatan transaksi, pertumbuhan ekonomi, dan tingkat kesejahteraan. Akan tetapi, penggunaan sarana pembayaran elektronik tersebut dapat meningkatkan risiko pada perekonomian dan sistem pembayaran, antara lain: peningkatan risiko default terutama pada instrumen kartu kredit (dan kartu pasca bayar). Hal tersebut dapat menimbulkan risiko sistemik dalam penyelesaian pembayaran antar bank, peningkatan risiko teknologi informasi yang dapat menimbulkan kekeliruan maupun kecurangan dalam proses penyelesaian transaksi, dan peningkatan risiko instabilitas sistem keuangan. ${ }^{20}$

Di dalam Fatwa Dewan Syariah Nasional-Majelis Ulama Indonesia Nomor: 116/DSN-MUI/IX/2017 tentang Uang Elektronik Syariah disebutkan bahwa yang dimaksud dengan uang elektronik (E-money) adalah alat pembayaran yang memenuhi unsur-unsur berikut: ${ }^{21}$

a. Diterbitkan atas dasar jumlah nominal uang yang disetor terlebih dahulu

18 Rachmadi Usman, "Karakteristik Uang Elektronik Dalam Sistem Pembayaran" Yuridika, Vol. 32 No. 1 (Januari, 2017): 135 - 188.

19 Veithzal Rifai, dkk, Bank dan Financial Institution Management (Jakarta: PT. Raja Grafindo Persada, 2001), 1367.

20 Ikaputera Waspada, "Percepatan Adopsi Sistem Transaksi Teknologi Informasi Untuk Meningkatkan Aksesibilitas Layanan Jasa Perbankan”, 122-131.

21 Fatwa Dewan Syariah Nasional-Majelis Ulama Indonesia Nomor: 116/DSN-MUI/IX/2017 tentang Uang Elektronik Syariah. Ditetapkan di Jakarta pada tanggal 19 September 2017. 
kepada penerbit;

b. Jumlah nominal uang disimpan secara elektronik dalam suatu media yang teregistrasi;

c. Jumlah nominal uang elektronik yang dikelola oleh penerbit bukan merupakan simpanan sebagaimana dimaksud dalam undang-undang yang mengatur mengenai perbankan; dan

d. Digunakan sebagai alat pembayaran kepada pedagangyang bukan merupakan penerbit uang elektronik tersebut.

Sedangkan yang dimaksud dengan uang elektronik syariah dalam fatwa ini adalah uang elektronik yang sesuai dengan prinsip-prinsip syariah.

Penggunaan e-money lebih nyaman dibandingkan uang tunai, untuk transaksi bernilai kecil, karena nasabah tidak perlu mempunyai sejumlah uang pas untuk transaksi dan kesalahan dalam menghitung pun dapat dikurangi. Selain itu, Gormez \& Capie menjelaskan bahwa e-money akan memengaruhi industri jasa keuangan di masa depan dan mampu mengurangi barrier dalam mengakses industri jasa keuangan. Pikkarainen, et al mengembangkan model penerimaan teknologi e-banking yang diambil dari salah satu teori tentang penggunaan sistem teknologi informasi (Technology Acceptance Model). Teori ini diperkenalkan pertama kali oleh Davis (1986) sebagai adaptasi dari Technology of Reason Action (TRA) dan TRA (Theory of Reasoned Action) oleh Ajzen \& Fishbein (1980). ${ }^{22}$

\section{Dasar Hukum Fatwa Uang Elektronik Syariah}

Penepatan fatwa DSN MUI tentang Uang Elektronik Syariah adalah dengan mengingat dan memperhatikan dalil-dalil berikut ini:

1. Firman Allah SWT:

a. Q.S. an-Nisa (4): 58:

"Sesunggubnya Allab menyurub kamu menyampaikan amanat kepada yang berbak menerimanya...".

b. Q.S. al-Maidah (5): 1:

"Hai orang yang beriman! Tunaikanlah akad-akad itu..."

c. Q.S. al-Isra' (17): 34:

"... Dan tunaikanlah janji-janji itu, sesunggubnya janji itu akan dimintai pertanggungjawaban... "

d. Q.S. an-Nisa' (4): 29:

22 Ikaputera Waspada, "Percepatan Adopsi Sistem Transaksi Teknologi Informasi Untuk Meningkatkan Aksesibilitas Layanan Jasa Perbankan”, 122-131. 
"Hai orang yang beriman! Janganlah kalian memakan (mengambil) harta orang lain secara batil, kecuali jika berupa perdagangan yang dilandasi atas sukarela di antara kalian...."

e. Q.S. Al-Kahfi (18): 19:

"Maka surublah salah seorang di antara kamu untuk pergi ke kota dengan membawa uang perakmu ini, dan hendaklah dia lihat manakah makanan yang paling baik, maka hendaklah ia membawa makanan itu untukmu, dan hendaklah ia berlaku lemah-lembut dan janganlah sekali-kali menceritakan balmu kepada seorang pun"

f. Q.S. al-Furqan (25): 67 :

"Dan orang-orang yang apabila membelanjakan (harta), mereka tidak berlebihlebihan, dan tidak (pula) kikir, dan adalah (pembelanjaan itu) di tengah-tengah antara yang demikian."

g. Q.S. al-Qashash (28'): 26:

"Salah seorang dari kedua wanita itu berkata, Hai ayabku! Ambillah ia sebagai orang yang bekerja (pada kita), karena sesunggubnya orang yang paling baik yang kamu ambil untuk bekerja (pada kita) adalab orang yang kuat lagi dapat dipercaya."

h. Q.S. al-Baqarah (2): 275 :

"Orang yang makan (mengambil) riba tidak dapat berdiri melainkan seperti berdirinya orang yang kemasukan syaitan lantaran (tekanan) penyakit gila. Keadaan mereka yang demikian itu adalah disebabkan mereka berkata (berpendapat), sesungguhnya jual beli itu sama dengan riba, padahal Allah telah menghalalkean jual beli dan mengharamkan riba. Orangyang telah sampai kepadanya larangan dari Tubannya, lalu terus berhenti (dari mengambil riba), maka baginya apa yang telah diambilnya dabulu (sebelum datang larangan); dan urusannya (terserab) kepada Allah. Orang yang mengulangi (mengambil riba), maka orang itu adalah penghuni-penghuni neraka; mereka kekal di dalamnya."

i. Q.S. al-Baqarah (2): 282:

"Hai orang yang beriman, jike kamu bermu'amalah tidak secara tunai sampai waktu tertentu, buatlah secara tertulis... "

\section{Hadis Nabi SAW:}

a. Hadits Nabi riwayat Muslim, Abu Daud, Tirmidzi, Nasa'i. dan Ibn Majah, dengan teks Muslim dari 'Ubadah bin Shamit:

"(Jual beli/pertukaran) emas dengan emas, perak dengan perak, gandum dengan gandum, sya'ir dengan sya'ir, kurma dengan kurma, dan garam dengan garam 
(disyaratkan harus dalam ukuran yang) sama (jika yang dipertukarkan) satu jenis dan (harus) secara tunai. Jika jenisnya berbeda, jualah sekehendakmu jika dilakukan secara tunai."

b. Hadis Nabi riwavat Muslim dari Abu Sa'id al-Khudri:

'Janganlah kamu menjual emas dengan emas kecuali sama (ukurannya) dan janganlah menambabkan sebagian atas sebagian yang lain; janganlah menjual perak dengan perak kecuali sama (ukurannya) dan janganlah menambabkan sebagian atas sebagian yang lain; dan janganlah menjual emas dan perak tersebut yang tidak tunai dengan yang tunai. "

c. Hadis Nabi riwayat Abu Daud dan Tirmidzi:

"Tunaikanlah amanah (titipan) kepada yang berhak menerimanya dan janganlah berkhianat kepada orang yang mengkhianatimu."

d. Hadis Nabi riwayat Ibnu Majah dari 'Ubadah bin al-Shamit r.a.,riwayat Ahmad dari Ibnu 'Abbas r.a., riwayat Malik dari bapaknya Yahya alMazini r.a." dan riwayat al-Hakim dan al-Dar al-Quthni dari Abu Sa'id al-Khudriy r.a.:

"Tidak boleh membahayakan/merugikan orang lain dan tidak boleh (pula) membalas bahaya (kerugian yang ditimbulkan oleh orang lain) dengan bahaya (perbuatan yang merugikannya).

e. Hadis Nabi riwayat al-Tirmidzi dart kakeknya' Amr bin 'Auf al-Muzani, dan riwayat al-Hakim dari kakeknya Katsir bin Abdillah bin 'Amr bin 'Auf r.a.:

"Shulb (penyelesaian sengketa melalui musyawarah untuk mufakat) boleh dilakukan di antara kaum muslimin kecuali shulh yang mengharamkan yang halal atau menghalalkan yang haram; dan kaum muslimin terikat dengan syarat-syarat yang mereka kecuali syarat yang mengharamkan yang halal atau menghalalkan yang haram. "

f. Hadis Nabi s.a.w. riwayat 'Abd ar-Razzaq dari Abu Hurairah r.a. dan Abu Sa'id al-Khudri r.a.:

"Barang siapa mempekerjakan pekerja, beritabukanlab upabnya."

g. Hadis Nabi riwayat Ibn Majah dari Ibnu Umar r.a., riwayat al-Thabrani dari Jabir r.a., dan riwayat al-Baihaqi dari Abu Hurairah r.a.:

"Berikanlah upah kepada pekerja sebelum keringatnya kering."

h. Hadis Nabi riwayat Muslim, dari 'Aisyah dan dari Tsabit dari Anas:

"Kalian lebih mengetahui urusan dunia kalian"

3. Kaidah fikih:

"Pada dasarnya, segala bentuk muamalat diperbolebkan kecuali ada dalil yang 
mengharamkannya alau meniadakan kebolehannya”.

"Segala dharar (bahaya/ kerugian) harus dibilangkan".

"Dharar (bahaya/ kerugian) harus dicegah sebisa mungkin".

"sesuatu yang berlaku berdasarkan adat' kebiasaan sama dengan sesuatu yang berlaku berdasarkan syara' (selama tidak bertentangan dengan syariat). "

"Hukum yang didasarkan pada adat (kebiasaan) berlaku bersama adat tersebut dan batal (tidak berlaku) bersamanya ketika adat itu batal, seperti mata uang dalam muamalat... "(Al-Qarafi., Anwar al-Buruq fi Anwa' al-Furuq, Jilid 2, b. 228) "(Dikutip) dari kitab al-Dzakhirah sebuah kaidah. Setiap hukum yang didasarkan pada suatu 'urf (tradisi) atau adat (kebiasaan masyarakat) menjadi batal (tidak berlaku) ketika adat tersebut hilang. Oleh karena itu, jika adat berubah, maka bukum pun berubah." (Al-Taj wa il-Iklil li-Mukhtashar Khalil, Jilid 7, h. 68)

"Kebijakan pemimpin terhadap rakyat harus mengikuti kepada kemashlahatan (masyarakat)".

"Di mana terdapat kemaslahatan, di sana terdapat bukum Allah"

Fatwa tentang uang elektronik syariah ini juga memperhatikan hal-hal berikut:

1. Diriwayatkan dari Umar bin Khattab, sebagaimana Tafsir al-Shan'any, Jilid 3, hal 93:

Umar bin Khattab berkata "Aku berkeinginan membuat uang dirham dari kulit unta", lalu dikatakan kepadanya "kalau begitu, tidak akan ada lagi unta..", lalu Umar mengurungkan niatnya"

2. Pendapat Imam Malik, dalam kitab Al-Mudawanah al-Kubra, Jilid 3, hal. 90:

"Andaikan masyarakat membolehkan uang dibuat dari kulit dan dijadikan sebagai alat tukar, pasti say a melarang uang kulit itu ditukar dengan emas dan perak secara tidak tunai"

3. Pendapat Ibn Hazm dalam kitab Al-Muhalla, Jilid 8, hal. 477:

"Segala sesuatu yang boleb diperjual-belikean boleh digunakan sebagai alat bayar, dan tidak. terdapat satu nash pun yang menyatakan bahwa uang harus terbuat dari emas dan perak"

4. Pendapat Ibn Taimiyah dalam Kitab Majmu' al-Fatawa, Jilid 19, hal. 251: "Adapun dinar dan dirbam, maka tidak ada batasan secara alami maupun secara syar'i, tapi rujukannya adalah pada kebiasaan ('adah) dan kesepakatan. Hal itu karena pada dasarnya tujuan orang (dalam penggunaan dinar dan dirbam) tidak berbubungan dengan substansinya, tetapi tujuannya adalah agar dinar dan dirham menjadi standar bagi objek. transaksi yang mereka lakukan. Fisik dinar dan dirham tidaklab dimaksudkan (bukan 
tujuan), tetapi hanya sebagai sarana untuk melakukan transaksi dengannya. Oleh karena itu, dinar dan dirham (banya) berfungsi sebagai tsaman (harga, standar nilai). Berbeda dengan harta yang lain (barang),' barang dimaksudkan untuk dimanfaatkan fisiknya. Oleh karena itu, barang harus diukur dengan perkara-perkara (ukuran-ukuran) yang bersifat alami atau syar'i. Sarana semata yang fisik maupun bentuknya bukan merupakan tujuan boleh digunakan untuk mencapai tujuan, seperti apa pun bentuknya. "

5. Uang-yang dalam literatur fiqh disebut dengan tsaman atau nuqud fiamak dari naqd)- didefinisikan oleh para ulama, antara lain, sebagai berikut:

"Naqd (uang) adalah segala sesuatu yang menjadi media pertukaran dan diterima secara umum, apapun bentuk dan dalam kondisi seperti apapun media tersebut." (Abdullah bin Sulaiman al-Mani', Bubuts./ i al-Iqtishad al-Islami, Mekab: al-Maktab al-Islami. 1996, h. 178)

"Naqd adalah sesuatu yang dijadikan harga (tsaman) oleh masyarakat, baik terdiri dari logam atau kertas yang dicetak maupun dari bahan lainnya, dan diterbitkan oleb lembaga keuangan pemegang otoritas." (Muhammad Rawas Qal'ah h. al-Mu'amalat al-Maliyah al-Mu'ashirahfi Dhau' al-Fiqh wa al-Sytari'ah, Beirut: Dar al-Nafa'is, 1999, h.23).

6. Surat permohonan fatwa perihal Uang elektronik yang sesuai dengan prinsip syariah dari PT Veritra Sentosa Internasional (VSI) Nomor: 043/Treni/ Legal/2017 tanggal 04 April 2017.

7. Hasil Diskusi "Kajian Uang Elektronik Ditinjau dari Kesesuaian PrinsipPrinsip Syariah" antara Tim Paytren dengan Tim Dewan Syariah Nasional Majelis Ulama Indonesia (DSN-MUI), di Jakarta, tanggal 22 Agustus 2017.

8. Pendapat dan saran Working Group Perbankan Syariah (WGPS) yang terdiri atas DSN-MUI, OJK, DSAS-IAI, dan Mahkamah Agung, tanggal 07 September 2017 di Jakarta.

9. Pendapat peserta Rapat Pleno Dewan Syariah Nasional-Majelis Ulama Indonesia pada hari Selasa tanggal 28 Dzulhijjah 1438 H/19 September 2017.

\section{Hukum Uang Elektronik Berdasarkan Fatwa DSN-MUI Tentang Uang Elektronik Syariah}

Sebelum menganalisis hukum uang elektronik berupa kartu flazz BCA, Go-Pay, dan Grab-Pay, terlebih dahulu perlu diperhatikan beberapa ketentuan di dalam Fatwa DSN-MUI Nomor: 116/DSN-MUI/IX/2017 tentang Uang Elektronik Syariah. Uang elektronik syariah dalam fatwa ini adalah uang elektronik yang sesuai dengan prinsip-prinsip syariah. Jumlah nominal uang elektronik adalah 
jumlah nominal uang yang disimpan secara elektronik yang dapat dipindahkan karena keperluan transaksi pembayaran dan/atau transfer dana. Penerbit adalah bank atau lembaga selain bank yang menerbitkan uang elektronik. Pemegang uang elektronik adalah pihak yang menggunakan uang elektronik. Prinsipal adalah bank atau lembaga selain bank yang bertanggungjawab atas pengelolaan sistem dan/ atau jaingan antar anggotanya yang berperan sebagai penerbit dan/atau acquirer, dalam transaksi uang elektronik yang kerjasama dengan anggotanya didasarkan atas suatu perjanjian tertulis. Sementara Acquirer adalah bank atau lembaga selain bank yang melakukan kerja sama dengan pedagang sehingga pedagang mampu memproses transaksi dari uang elektronik yang diterbitkan oleh pihak selain acquirer yang bersangkutan; dan bertanggungjawab atas penyelesaian pembayaran kepada pedagang. Pedagang (merchant) adalah penjual barang dan atau jasa yang menerima transaksi pembayaran dari Pemegang. ${ }^{23}$

Dalam fatwa Nomor: 116/DSN-MUI/IX/2017 tentang Uang Elektronik Syariah ini disebutkan bahwa uang elektronik boleh digunakan sebagai alat pembayaran dengan mengikuti ketentuan yang terdapat dalam fatwa ini. Ketentuan tersebut sebagai berikut: ${ }^{24}$

Ketentuan terkait Akad dan Personalia Hukum

1. Akad antara penerbit dengan pemegang uang elektronik adalah akad wadi'ah atau akad qardh.

a. Dalam hal akad yang digunakan adalah akad wadiah, maka berlaku ketentuan dan batasan akad wadi'ah sebagai berikut:

1) Jumlah nominal uang elektronik bersifat titipan yang dapat diambil/ digunakan oleh pemegang kapan saja;

2) Jumlah nominal uang elektronik yang dititipkan tidak boleh digunakan oleh penerima titipan (penerbit), kecuali atas izin pemegang kartu;

3) Dalam hal jumlah nominal uang elektronik yang dititipkan digunakan oleh penerbit atas izin pemegang kartu, maka akad titipan (wadiah) berubah menjadi akad pinjaman (qardh), dan tanggungjawab penerima titipan sama dengan tanggungjawab dalam akad qardh.

4) Otoritas terkait wajib membatasi penerbit dalam penggunaan dana titipan dari pemegang kartu (dana float).

5) Penggunaan dana oleh penerbit tidak boleh bertentangan dengan prinsip syariah dan peraturan pemndang-undangan.

23 Fatwa Dewan Syariah Nasional-Majelis Ulama Indonesia Nomor: 116/DSN-MUI/IX/2017 tentang Uang Elektronik Syariah. Ditetapkan di Jakarta pada tanggal 19 September 2017.

24 Fatwa Dewan Syariah Nasional-Majelis Ulama Indonesia Nomor: 116/DSN-MUI/IX/2017 tentang Uang Elektronik Syariah. Ditetapkan di Jakarta pada tanggal 19 September 2017. 
b. Dalam hal akad yang digunakan adalah akad qardh, maka berlaku ketentuan dan batasan akad qardh sebagai berikut:

1) Jumlah nominal uang elektronik bersifat hutang yang dapat diambil/ digunakan oleh pemegang kapan saja.

2) Penerbit dapat menggunakan (menginvestasikan) uang hutang dari pemegang uang elektronik.

3) Penerbit wajib mengembalikan jumlah pokok piutang pemegang uang elektronik kapan saja sesuai kesepakatan;

4) Otoritas terkait wajib membatasi penerbit dalam penggunaan dana pinjaman (utang) dari pemegang kartu (dana float).

5) Penggunaan dana oleh penerbit tidak boleh bertentangan dengan prinsip syariah dan peraturan perundang-undangan.

2. Di antara akad yang dapat digunakan penerbit dengan para pihak dalam penyelenggaraan uang elektronik (prinsipal, acquirer, pedagang (merchant), penyelenggara kliring, dan penyelenggara penyelesai akhir) adalah akad ijarah, akad jualah, dan akad wakalah bi al-ujrah.

a. Dalam hal akad yang digunakan akad ijarah, maka berlaku ketentuan dan batasan akad ijarah sebagaimana terdapat dalam DSN-MUI Nomor: 112/ DSN-MUI/IX/2017 tentang Akad Ijarah.

b. Dalam hal akad yang digunakan akad ju'alah, maka berlaku ketentuan dan batasan akad jualah sebagaimana terdapat dalam DSN-MUI Nomor: 62/ DSN-MUI/XII/2007 tentang Akad Ju'alah.

c. Dalam hal akad yang digunakan akad wakalah bi al-ujrah, maka berlaku ketentuan dan batasan akad wakalah bi al-ujrah sebagaimana terdapat dalam DSN-MUI Nomor: 113/DSN-MUI/IX/2017 tentang Wakalah bi al-Ujrah.

3. Di antara akad yang dapat digunakan antara penerbit dengan agen layanan keuangan digital adalah akad ijarah, akad ju'alah, dan akad wakalah bi al-ujrah.

a. Dalam hal akad yang digunakan akad ijarah, maka berlaku ketentuan dan batasan akad ijarah sebagaimana terdapat dalam DSN-MUI Nomor: 112/ DSN-MUI/IX/2017 tentang Akad Ijarah.

b. Dalam hal akad yang digunakan akad ju'alah, maka berlaku ketentuan dan batasan akad ju'alah sebagaimana terdapat dalam DSN-MUI Nomor: 62IDSN-MUI/XII/2007 tentang Akad Ju'alah.

c. Dalam hal akad yang digunakan akad wakalah bi al-ujrah, maka berlaku ketentuan dan batasan akad wakalah bi al-ujrah sebagaimana terdapat dalam DSN-MUI Nomor: 113/DSN-MUI/IX/2017 tentang Wakalah bi 
al-Ujrah.

\section{Ketentuan Biaya Layanan Fasilitas}

Dalam penyelenggaraan uang elektronik, penerbit dapat mengenakan biaya layanan fasilitas uang elektronik kepada pemegang dengan ketentuan sebagai berikut: 1. Biaya-biaya layanan fasilitas harus berupa biaya riil untuk mendukung proses kelancaran penyelenggaraan uang elektronik; dan

2. Pengenaan biaya-biaya layanan fasilitas harus disampaikan kepada pemegang kartu secara benar sesuai syariah dan peraturan perundang-undangan yang berlaku.

\section{Ketentuan dan Batasan Penyelenggaraan dan Penggunaan Uang Elektronik}

Penyelenggaraan dan penggunaan uang elektronik wajib terhindar dari :

1. Transaksi yang ribawi, gharar, maysir, tadlis, risywah, dan israf:, dan

2. Transaksi atas objek yang haram atau maksiat.

\section{Ketentuan Khusus}

1. Jumlah nominal uang elektronik yang ada pada penerbit harus ditempatkan di bank syariah.

2. Dalam hal kartu yang digunakan sebagai media uang elektronik hilang maka jumlah nominal uang yang ada di penerbit tidak boleh hilang.

Berdasarkan ketentuan fatwa tersebut, maka akan dibahas bagaimana kebolehan menggunakan e-money berikut:

1. Kartu Flazz BCA

Kartu Flazz BCA merupakan e-money yang diterbitkan oleh PT Bank Central Asia Tbk. BCA sudah menerbitkan e-money sejak 3 Juli 2009. BCA menawarkan kecepatan bertransaksi dengan teknologi chip dan RFID (Radio Frequency Identification) dalam sebuah kartu Flazz. Cukup dengan sentuhan dalam hitungan detik, transaksi sehari-hari dapat dilakukan dengan cepat dan praktis. Kepraktisan melakukan pembayaran dengan Flazz karena tidak perlu membawa uang tunai dalam jumlah banyak, juga tidak perlu menyimpan kembalian recehan. Pembayaran bisa dilakukan dengan amat mudah karena cukup meletakkan kartu pada Reader, maka seketika transaksi selesai dilakukan. Selembar kartu Flazz memiliki multifungsi karena bisa digunakan untuk pembayaran di Tol, food and beverage, minimarket, supermarket, hipermarket, 
SPBU, parkir, toko buku, tempat rekreasi, transportasi umum (Transjakarta, Commuter Line Jabodetabek dan Trans Jogja) dan banyak lagi jenis merchant lainnya di lebih dari 57 ribu outlet merchant. Isi ulang (Top Up) sudah dapat dilakukan dengan sumber dana uang tunai. Banyak keuntungan yang juga dapat diperoleh seperti: mempercepat layanan karena tidak perlu mengecek keaslian uang dan menghitung uang saat bertransaksi. Selain itu, juga membantu cash handling dan pelaporan transaksi.

Berdasarkan Fatwa DSN-MUI Nomor: 116/DSN-MUI/IX/2017 tentang Uang Elektronik Syariah, maka kartu Flazz BCA tidak boleh digunakan karena tiga hal, yaitu:

a. Jumlah nominal uang elektronik yang ada pada penerbit tidak ditempatkan di Bank Syariah, padahal dalam fatwa disebutkan harus ditempatkan di bank syariah.

b. Dalam hal kartu yang digunakan sebagai media uang elektronik hilang maka jumlah nominal uang yang ada di penerbit hilang, sedangkan ketentuan fatwa mensyaratkan dalam kondisi demikian uang pemegang tidak boleh hilang.

c. Jumlah nominal uang elektronik tidak bisa diuangkan/diambil lagi.

2. Go-Pay

Layanan transportasi online semakin hari semakin memanjakan masyarakat Indonesia. alat transportasi berbasis online memberikan beberapa kemudahan, measyarakat menjadi lebih leluasa dalam memilih kendaraan roda dua atau roda empat, tidak perlu berdesak-desakan dengan orang lain, dan dijemput serta diantar sampai ke alamat. Selain kemudahan ini, transportasi online juga memberikan kemudahan pembayaran tidak secara tunai.

Go-Jek merupakan salah satu perusahaan yang menyediakan jasa transportasi online. Layanan utamanya adalah go-ride dan go-car. Selain itu, Go-Jek juga menyediakan jasa go-food yang khusus mengantarkan makanan jika malas keluar rumah, go-send berupa layanan pengiriman barang. Go-Bluebird layanan taxi. Go-Pulsa berupa layanan untuk pengisian pulsa. Go-Clean berupa layanan untuk membersihkan rumah, dan go-massage berupa layanan tukang pijit, dan berbagai layanan lainnya.

Sebagai layanan moda transportasi yang banyak digunakan masyarakat, Go-Jek memberikan kemudahan bertransaksi dengan memperkenalkan go-pay sebagai layanan pembayaran. Go-Pay adalah dompet virtual untuk menyimpan Go-Jek credit yang bisa digunakan untuk membayar transaksi-transaksi yang berkaitan 
dengan layanan di dalam aplikasi Go-Jek. Saat ini go-pay sudah terintegrasi dengan bank-bank besar di Indonesia demi kemudahan masyarakat melakukan isi saldo go-pay. Beberapa bank besar yang menjadi mitra go-pay adalah BCA, bank Mandiri, bank BRI, BNI, Permata Bank, CIMB Niaga, serta pengisian via ATM bersama dan Prima. Pengisian saldo go-pay juga bisa dilakukan melalui Alfamart dan driver. ${ }^{25}$

Ada satu layanan khusus yang dimiliki go-pay yang belum dimiliki oleh e-money lainnya, yaitu adanya fitur untuk menarik kembali jumlah nominal e-money kita. Jumlah nominal go-pay bisa ditransfer ke rekening pengguna, dalam artian saldo go-pay bisa diuangkan.

Berdasarkan Fatwa DSN-MUI Nomor: 116/DSN-MUI/IX/2017 tentang Uang Elektronik Syariah, maka go-pay tidak boleh digunakan karena jumlah nominal uang elektronik yang ada pada penerbit tidak ditempatkan di Bank Syariah, padahal dalam fatwa disebutkan harus ditempatkan di bank syariah.

3. Grab-Pay

Grab merupakan sebuah perusahaan asal Malaysia yang melayani aplikasi penyedia transportasi dan tersedia di enam negara, yakni Malaysia, Singapura, Thailand, Vietnam, Filipina, dan Indonesia. Di Indonesia Grab melayani ojek, mobil, taksi, pengiriman barang, pembelian makanan, dan penyewaan mobil. Grab memiliki layanan uang elektronik berupa grab-pay yang bisa digunakan oleh pengguna sebagai pembayaran. Dengan grab-pay pengguna tidak perlu melakukan pembayaran tunai, memikirkan kembalian, cukup naik dan turun ojek atau mobil tanpa perlu melakukan transaksi kembalian dan lain-lain. Top up grab-pay bisa dilakukan melalui bank, ATM, alfamart, dan driver. Grab-pay tidak menyediakan fitur untuk tarik uang elektronik. Dalam artian e-money grab-pay tidak bisa diambil/diuangkan. ${ }^{26}$

Berdasarkan Fatwa DSN-MUI Nomor: 116/DSN-MUI/IX/2017 tentang Uang Elektronik Syariah, maka Grab-Pay tidak boleh digunakan karena dua hal, yaitu:

a. Jumlah nominal uang elektronik yang ada pada penerbit tidak ditempatkan di Bank Syariah, padahal dalam fatwa disebutkan harus ditempatkan di bank syariah.

b. Jumlah nominal uang eletronik grab-pay tidak bisa diambil/diuangkan oleh pemegang uang elektronik.

25 www.go-jek.com

26 www.go-jek.com 
Berdasarkan analisis di atas, maka e-money berupa kartu Flazz BCA, Go-Pay, dan Grab-Pay tidak boleh digunakan sebagai alat pembayaran berdasarkan fatwa DSN-MUI Nomor: 116/DSN-MUI/IX/2017 tentang Uang Elektronik Syariah. Hal ini karena beberapa hal yang tidak sesuai dengan ketentuan fatwa, yaitu: Jumlah nominal uang elektronik yang ada pada penerbit tidak ditempatkan di bank Syariah, padahal dalam fatwa disebutkan harus ditempatkan di bank syariah. Sementara dalam hal kartu yang digunakan sebagai media uang elektronik hilang, maka jumlah nominal uang yang ada di penerbit hilang, padahal ketentuan fatwa mensyaratkan dalam kondisi demikian uang pemegang tidak boleh hilang, dan jumlah nominal uang elektronik tidak bisa diuangkan/diambil lagi.

Ada satu hal yang perlu menjadi perhatian kita semua, bahwa Per 8 Januari 2018 Daftar Penyelenggara Uang Elektronik yang Telah Memperoleh Izin dari Bank Indonesia ada 26 perusahaan. Ada berupa perbankan dan ada non-bank. 26 perusahaan tersebut di antaranya: $:^{27}$

1. PT Artajasa Pembayaran Elektronis, 21 November 2012

2. PT Bank Central Asia Tbk, 3 Juli 2009

3. PT Bank CIMB Niaga, 27 Maret 2013

4. PT Bank DKI, 3 Juli 2009

5. PT Bank Mandiri (Persero) Tbk, 3 Juli 2009

6. PT Bank Mega Tbk, 3 Juli 2009

7. PT Bank Negara Indonesia (Persero) Tbk, 3 Juli 2009

8. PT Bank Nationalnobu, 29 april 2013

9. PT Bank Permata, 23 Januari 2013

10. PT Bank Rakyat Indonesia , 29 Desember 2010

11. PT Finnet Indonesia, 1 Juli 2012

12. PT Indosat, Tbk, 3 Juli 2009

13. PT Nusa Satu Inti Artha (DOKU), 25 Maret 2013

14. PT Skye Sab Indonesia, 3 Juli 2009

15. PT Telekomunikasi Indonesia, Tbk, 3 Juli 2009

16. PT Telekomunikasi Seluler, 3 Juli 2009

17. PT XL Axiata, Tbk, 11 Maret 2011

18. PT Smartfren Telecom Tbk, 16 Juni 2014

19. PT Dompet Anak Bangsa (Go-Pay), 29 September 2014

20. PT Witami Tunai Mandiri (True Money), 5 Januari 2015

27 www.bi.go.id 
21. PT Espay Debit Indonesia Koe, 20 Juni 2016

22. PT Bank QNB Indonesia Tbk, 1 Maret 2017

23. PT BPD Sumsel Babel, 4 April 2017

24. PT Buana Media Teknologi, 29 Mei 2017

25. PT Bimasakti Multi Sinergi, 4 Juni 2017

26. PT Visionet Internasional (OVO), 22 Agustus 2017.

Dari 26 perusahaan penerbit e-money, tidak satupun yang menempatkan dananya di bank Syariah. Hanya ada satu perusahaan penerbit yang menempatkan dananya di bank Syariah yaitu PT Veritra Sentosa Internasional (VSI), namun dekimian belum memperoleh izin dari Bank Indonesia. Hal ini menyebabkan PT VSI tidak bisa menjalankan operasionalnya karena melanggar Peraturan Bank Indonesia Nomor: 11/12/PBI/2009 tentang Uang elektronik yang telah dirubah menjadi PBI Nomor 18/17/PBI/2016 tentang perubahan kedua atas Peraturan Bank Indonesia Nomor: 11/12/PBI/2009 tentang Uang elektronik. Dalam PBI tersebut disebutkan bahwa setiap perusahaan penerbit e-money harus mendapatkan izin dari Bank Indonesia.

\section{Simpulan}

Berdasarkan analisis di atas, maka e-money berupa kartu Flazz BCA, GoPay, dan Grab-Pay tidak boleh digunakan sebagai alat pembayaran berdasarkan fatwa DSN-MUI Nomor: 116/DSN-MUI/IX/2017 tentang Uang Elektronik Syariah. Hal ini karena beberapa hal yang tidak sesuai dengan ketentuan fatwa, yaitu: Jumlah nominal uang elektronik yang ada pada penerbit tidak ditempatkan di bank Syariah, padahal dalam fatwa disebutkan harus ditempatkan di bank syariah. Dalam hal kartu yang digunakan sebagai media uang elektronik hilang, maka jumlah nominal uang yang ada di penerbit pun hilang, padahal ketentuan fatwa mensyaratkan dalam kondisi tersebut uang pemegang tidak boleh hilang, dan jumlah nominal uang elektronik tidak bisa diuangkan/diambil lagi.

Dalam rangka mengakomodir kepentingan kemudahan bertransaksi masyarakat Indonesia yang mayoritas muslim, maka MUI perlu mendorong perusahaan penerbit agar menempatkan dananya di bank Syariah dan mendorong perusahaan penerbit mengeluarkan layanan e-money sesuai dengan fatwa DSN MUI Nomor: 116/DSN-MUI/IX/2017 tentang Uang Elektronik Syariah. Selain itu, perlu adanya intervensi dari Bank Indonesia untuk mempercepat proses implementasi e-money berdasarkan syariah. 


\section{Daftar Pustaka}

\section{Buku}

al-Mani', Abdullah bin Sulaiman. Buhuts fi al-iqtishad al-Islami., Mekah: al-Maktab alIslami, 1996.

Bank for Internatinal Settlement. Implications for central bank of the development of electronic money. Basel: BIS, 1996.

Karim, Adiwarman A. Ekonomi Makro Islami. Jakarta: PT. Raja Grafindo Persada, 2008.

Miskin, Frederic S. The Economic of Money, Banking, and Financial Market. New York: Addison Wesley Longman, 2001.

Rifai, Veithzal dkk. Bank dan Financial Institution Management. Jakarta: PT. Raja Grafindo Persada, 2001.

Rogers, Colin. Money, Interest and Capital: A Study in the Foundation of Monetery Theory. Cambridge: Cambridge University Press, 1989.

Committee on Payment and Settlement Systems. Survey of Developments in Electronic Money and Internet and Mobile Payments. Bank for International Settlements 2004.

Fatwa Dewan Syariah Nasional - Majelis Ulama Indonesia Nomor: 116/DSN-MUI/ IX/2017 tentang Uang Elektronik Syariah. Ditetapkan di Jakarta pada tanggal 19 September 2017.

Fatwa Dewan Syariah Nasional Majelis Ulama Indonesia NO: 19/DSN-MUI/IV/2001 Tentang Al-Qardh

Fatwa DSN-MUI Nomor: 112/DSN-MUI/IX/2017 tentang Akad Ijarah

Fatwa DSN-MUI Nomor: 62/DSN-MUI/XII/2007 tentang Akad Ju'alah

Fatwa DSN-MUI Nomor: 113/DSN-MUI/IX/2017 tentang Wakalah bi al-Ujrah

Fatwa DSN-MUI Nomor: 112/DSN-MUI/IX/2017 \&ntang Akad Ijarah

Fatwa DSN-MUI Nomor: 62IDSN-MUI/XII/2007 tentang Akad Ju'alah

Fatwa DSN-MUI Nomor: 113/DSN-MUI/IX/2017 tentang Wakalah bi al-Ujrah.

Peraturan Bank Indonesia Nomor: 11/12/PBI/2009 tentang Uang Elektronik (electronic 
money).

\section{Artikel}

Abidin, Muhammad Sofyan. "Dampak Kebijakan E-Money di Indonesia Sebagai Alat Sistem Pembayaran Baru” Jurnal AKuntansi UNESA, Vol 3, No 2, (2015).

Nunan, Daniel dan Victoria Insley, "Gamification and the online retail experience”, International Journal of Retail \&amp; Distribution Management, Vol. 42, Issue 5, (2014):340-351.

Usman, Rachmadi. "Karakteristik Uang Elektronik Dalam Sistem Pembayaran” Yuridika, Volume 32 No. 1, (Januari 2017): 135 - 188.

Waspada, Ikaputera. "Percepatan Adopsi Sistem Transaksi Teknologi Informasi Untuk Meningkatkan Aksesibilitas Layanan Jasa Perbankan” Jurnal Keuangan dan Perbankan, Vol.16, No.1 (Januari 2012): 122-131.

\section{Internet}

Lauer, Kate dan Michael Tarazi. 'Supervising Nonbank E-Money Issuers' (CGAP, 2010) www.cgap.org/.../CGAP-Brief-Supervising-Nonbank-Emoney accessed 11 March 2018.

Tarazi, Kate Lauer dan Michael, “Supervising Nonbank E-Money Issuers' (CGAP, 2010) <www.cgap.org/.../CGAP-Brief-Supervising-Nonbank-Emoney-> Diakses 11 Februari 2019.

www.go-jek.com

www.bi.go.id 